УДК 355(044)069(2014/2019)

DOI: $10.33099 / 2707-1383-2020-38-4-238-244$

Пашкова О.О., науковий співробітник

науково-дослідного відділу

проблем історії війн і воєнного мистецтвва науково-дослідного иентру воєнної історії

Національного університету оборони Украӥни імені Івана Черняховського (м. Київ, Украӥна)

ORCID: https://orcid.org/0000-0002-6525-4613

\title{
РОЛЬ ВІЙСЬКОВИХ МУЗЕЇВ У ВІЙСЬКОВО-ПАТРІОТИЧНОМУ ВИХОВАННІ КУРСАНТІВ ВИЩИХ ВІЙСЬКОВИХ НАВЧАЛЬНИХ ЗАКЛАДІВ В УМОВАХ ЗБРОЙНОЇ АГРЕСІЇ ПРОТИ УКРАЇНИ
}

\begin{abstract}
У статті розглянуто основні напрями діяльності вітчизняних військових музеїв упродовж 2014-2019 років у контексті військово-патріотичного виховання майбутніх офрічерів Збройних Сил Украӥни та допризовної молоді. Встановлено, щзо оновлення експозицій музеїв вищих військових навчальних закладів здійснювалося відповідно до вимог сучасних нормативно-правових документів у сфері наџіональної пам'яті та загроз начіональній безпечі в інформаџійній сфері. Значна увага у статті приділена відображенню в експозичіях військових музеїв участі військових підрозділів та окремих військовослужбовців в антитерористичній операції на Сході України.
\end{abstract}

Ключові слова: військовий музей, кімната традицій, експозиція, вищий військовий навчальний заклад, військово-патріотичне виховання, курсанти, Збройні Сили Украӥни.

Постановка проблеми. 3 початком збройного конфлікту на Сході України у 2014 році виникла нагальна необхідність посилення військово-патріотичного виховання особового складу Збройних Сил України, зокрема через поширення воєнно-історичних знань про Україну та iii військові формування, звернення до матеріальних пам'яток, пов'язаних зі збройним конфліктом у новітній історії держави, вжиття заходів по увічненню пам'яті учасників бойових дій тощо. Важливим засобом військово-патріотичного виховання залишаються військові музеї, кімнати традицій, меморіальні комплекси, історичні пам'ятки та предмети.

Аналіз останніх досліджень і публікацій. Діяльність сучасних вітчизняних музеїв у висвітленні участі представників сектору безпеки і оборони держави у збройному конфлікті, збереженні пам'яті про військовослужбовців - учасників бойових дій знайшла відображення у наукових працях фахівців музейної справи В. Карпова, Я. Тинченка, Д. Махтарова, I. Мороз, К. Ляшенко, В. Давидюк та інших.

Мета статті - висвітлити основні підходи до використання експозицій роботи військових музеїв України у поширенні знань про історію України, зростання їх ролі у військово-патріотичному вихованні майбутніх офіцерів Збройних Сил України з урахуванням подій гібридної війни Росії проти України.

Виклад основного матеріалу. Важливе місце у системі військово-патріотичного 
виховання майбутніх офіцерів ЗС України належить військовим музеям та музеям (кімнатам) традицій вищих військових навчальних закладів через проведення екскурсій, організацію виставок, наукових конференцій, присвячених воєнно-історичним подіям та знаменним датам української історії тощо. Їх діяльність є важливим засобом військово-патріотичного виховання завдяки поширенню знань про історичне минуле України, формуванню шанобливого ставлення до національної воєнно-історичної спадщини.

Виготовлення тематичних експозиційних виставок, присвячених історії розвитку українського війська, приведення музейних експозицій військових музеїв у відповідність до вимог закону «Про декомунізацію» 3 обов'язковим відображенням подій, пов'язаних із відбиттям російської збройної агресії було визначено Програмою заходів щодо відновлення та впровадження національних бойових традицій у Збройних Силах України [1].

Недостатній рівень організаційної роботи з приведенням музейних експозицій iз історії навчальних закладів у відповідність до законодавства України щодо засудження тоталітарних режимів, необхідність посилення заходів по відображенню подій, пов'язаних з участю ЗС України у відбитті російської збройної агресії [2] зумовлювали прийняття відповідних документів Міністерством оборони України та Генерального штабу ЗС України.

Основні розділи типових експозицій військових музеїв вміщувало розроблене та затверджене у липні 2018 року Положення про організацію діяльності військових музеїв, музеїв (кімнат) бойових традицій у Збройних Силах України. Зокрема, у музеях вищих військових навчальних закладів передбачалося розміщення таких розділів: етапи державотворення в Україні; створен- ня та функціонування українського війська у різні історичні епохи; створення закладу; його бойовий шлях; участь особового складу у бойових діях із захисту суверенітету і територіальної цілісності України; видатні військовослужбовці закладу, які відзначились при захисті незалежності України; досягнення закладу під час здійснення повсякденної діяльності; відомості про край за місце дислокації закладу [3].

У свою чергу, рекомендації Департаменту військової освіти, науки, соціальної та гуманітарної політики МО України визначали основні напрями музейної роботи військових музеїв військових частин, установ, закладів Міністерства оборони України та Збройних Сил України, а саме:

- внесення змін до матеріалів експозицій музеїв, а за потреби, проведення реекспозиції, у музеях, що висвітлюють події періоду Другої світової війни або події, які довго замовчували чи трактували з позицій ідеологів радянського періоду; — приведення у відповідність до трактувань української та світової історичної науки термінів, що вживають у музейних експозиціях, у тому числі періоду Другої світової війни;

— аналіз та перевірку історичної достовірності окремих дат, тверджень, посилань та оцінок подій і фактів, розміщених в експозиціях музеїв;

- використання комуністичної та нацистської символіки винятково як музейних предметів;

- оновлення експозиції музеїв, кімнат бойових традицій з обов'язковим представленням інформації про героїв антитерористичної операції/операції Об'єднаних сил;

- збір матеріалів, присвячених бойовим діям на Сході України, а саме: фото-, відеоматеріалів; речей військовослужбовців, які відзначились під час бойо- 
вих дій; предметів уніформи; відзнак; спорядження; елементів державної символіки, що використовувались військовослужбовцями у районі проведення бойових дій; побутові речі, що мають сліди ураження різними типами зброї тощо;

- проведення зустрічей із учасниками та свідками важливих військових подій XX та XXI століть, а також родичами учасників тих подій з метою документування окремих фактів, біографічних відомостей, отримання матеріалів для музею тощо [4].

Щодо періоду Другої світової війни, то визначальним в екскурсійній тематиці, в експозиціях музеїв, проведенні виховних заходів на їхній базі рекомендовано робити акцент на українському вимірі перемоги, здобутків і втрат на тлі світової історії. Також рекомендації містили пропозиції Українського інституту національної пам'яті щодо термінів, що висвітлюють події Другої світової війни, зокрема відмовитися від вживання «Велика Вітчизняна війна», замінивши його історично коректним - «Друга світова війна»; «фашистські загарбники» - «нацистські окупанти»; «визволення України від фашистських загарбників» - «вигнання нацистських окупантів із України». Рекомендації пропонували також спростування низки міфів російської пропаганди, пов'язаних із Другою світовою війною.

Особливу увагу рекомендували приділити відображенню в експозиціях музеїв інформації про героїчні вчинки військовослужбовців 3С України, бійців добровольчих формувань, волонтерів та інших громадян, які зробили значний внесок у зміцнення обороноздатності України, поповненню музейних фондів предметами, пов'язаними 3 веденням бойових дій на Сході України проти російської агресії, участю Збройних Сил України у миротворчих операціях. Та- ким чином, оновлення експозицій музеїв зосереджувалось переважно на висвітленні подій Другої світової війни і антитерористичної операції на Сході України, що зумовлено необхідністю посилення військово-патріотичного виховання особового складу, а також протидії негативним інформаційним впливам противника при фальсифікації воєнно-історичних подій.

Так, діяльність військових музеїв у вищих військових навчальних закладах проводилась відповідно до вимог документів. У 2015 році у музеї Харківського національного університету Повітряних Сил імені Івана Кожедуба розроблено експозицію, присвячену випускникам закладу, які брали участь в антитерористичній операції. В експозиції представлено відтворену землянку, де перебували військовослужбовці під час бойових дій, фотографії із відображенням бойових дій на Сході України, дитячі малюнки та обереги, виконані для військовослужбовців, які виконували завдання у районі проведення антитерористичної операції, розміщено фотогалерею випускників, які брали участь та загинули під час виконання бойових завдань, діораму боїв за Донецький аеропорт.

У музеї Військової академії (м. Одеса) відкрито зал, присвячений подіям сучасної воєнної історії України. Тут представлено особисті речі випускників одеських військових вишів, які удостоєні звання Герой України, стенди 3 інформацією про випускників закладу, які загинули під час виконання військового обов'язку на Сході України.

У музеї Бойової слави на факультеті військової підготовки імені Верховної Ради України НТУ «ХПІ» було створено експозиції, що містили фото із району бойових дій, військове спорядження, обереги, документи, особисті речі учасників антитерористичної операції, а також «Книга 
пам'яті» та «Книга пошани». У кімнатах традицій факультету розміщено стенди 3 описом вчинків випускників під час виконання завдань у ході бойових дій на Сході України, встановлено куточки з висвітленням подій антитерористичної операції та інформації про військовослужбовців, які навчалися на факультеті. У курсантському гуртожитку за ініціативи курсантів було сформовано експозицію Слави Героя на знак поваги до виняткової мужності, героїзму та самопожертви, виявлену капітаном Олександром Лавренком, який довічно зарахований до списку факультету. Підготовлено також експозицію випускникам закладу, які залучалися до виконання завдань на Сході України, що відкрито у музеї Національної академії сухопутних військ імені гетьмана Петра Сагайдачного.

Події сучасної воєнної історії України відображено в діяльності краєзнавчих та історико-краєзнавчих музеях України: збір і вивчення матеріалів, пов'язаних із антитерористичною операцією; фіксацію усних свідчень безпосередніх учасників подій; започаткування нових експозицій, популяризація внеску місцевих мешканців у захист територіальної цілісності держави; протидія ворожій пропаганді, створення можливостей для комунікації військовослужбовців із молоддю 3 метою військово-патріотичного виховання через організацію зустрічей із учасниками бойових дій, вечорів пам'яті тощо [5, с. 211, 212; 6, c. 205].
Поповнення фондів Національного військово-історичному музею України проведено завдяки участі військовослужбовців-учасників бойових дій, родичам та побратимам загиблих. Працівники музею беруть безпосередню участь в пошукових місіях «Евакуація-200» [7, с. 262; 8, с. 271]. Збір матеріальних пам'яток у районі проведення антитерористичної операції дало змогу створити постійно діючі експозиції, що вміщують особисті речі, зброю, уніформу учасників бойових дій, зразки боєприпасів, що використовувалися противником проти українських сил, предмети спорядження збройних сил Російської Федерації та незаконних збройних формувань тощо $[9$, c. 126,128$]$.

Висновок. Таким чином, діяльність цивільних і військових музейних установ як важливих засобів військово-патріотичного виховання у досліджуваний період спрямовувалася на відновлення історичної пам'яті про українські військові традиції, донесення до відвідувачів ідеї української державності як консолідуючого чинника розвитку суспільства і нації із урахуванням сучасних викликів та загроз національній безпеці України. Важливе місце у діяльності музейних установ зайняло відображення подій антитерористичної операції на Сході України, що зумовило оновлення та поповнення фондів, створення тематичних експозицій, проведення екскурсій та виставок, приурочених воєнно-історичним подіям сучасної воєнної історії України.

\section{СПИСОК ВИКОРИСТАНИХ ДЖЕРЕЛ}

1. Наказ Генерального штабу Збройних Сил України № 166 «Про затвердження Програми заходів щодо відновлення та впровадження національних бойових традицій у Збройних Силах України» від 25.04.2018.

2. Наказ Міністерства оборони України від № 91 КП «Про стан впровадження вимог законодавства України щодо засудження комуністичного режиму» від 24.05.2018. 
3. Наказ Міністерства оборони України № 343 «Про затвердження Положення про організацію діяльності військових музеїв, музеїв (кімнат) бойових традицій у Збройних Силах України» від 17.07.2018.

4. Методичні рекомендації щодо типової тематики інформаційного наповнення музейних експозицій військових музеїв та музеїв (кімнат) бойових традицій військових частин, установ закладів Міністерства оборони України та Збройних Сил України.

5. Зборовський А. Відображення героїзму і трагедії ірпінських учасників АТО в експозиції Ірпінського історико-краєзнавчого музею / А. Зборовський // Матеріали Всеукраїнської наукової військово-історичної конференції (м. Київ, 19 квітня 2018 р.). - К., Національний військово-історичний музей України. - 2018. - С. 211-213.

6. Зек Б. Заходи військово-патріотичного спрямування Волинського краєзнавчого музею у зв'язку з проведенням АТО і ООС на Донбасі / Б. Зек // Матеріали Всеукраїнської наукової військово-історичної конференції (м. Київ, 19 квітня 2018 р.). - К., Національний військово-історичний музей України. - 2018. - С. 204-207.

7. Давидюк В. Комплектування фондів Національного військово-історичного музею України предметами із зони АТО / В. Давидюк // Матеріали Всеукраїнської наукової військово-історичної конференції (м. Київ, 23 вересня 2015 р.). - К., Національний військово-історичний музей України. - 2015. - С. 261-270.

8. Тинченко Я., Корнієнко О., Махтаров Д. Експозиційно-виставкова діяльність Національного військово-історичного музею України, що відображає анексію Автономної Республіки Крим та воєнні дії на сході країни / Я. Тинченко, О. Корнієнко, Д. Махтаров // Матеріали Всеукраїнської наукової військово-історичної конференції (м. Київ, 23 вересня 2015 р.). - К., Національний військово-історичний музей України. - 2015. - С. 271-293.

9. Мороз І., Ляшенко К. Робота Національного військово-історичного музею України з ушанування пам'яті загиблих у війні на Сході України / I. Мороз, К. Ляшенко // Матеріали III Всеукраїнської наукової військово-історичної конференції (м. Київ, 19 квітня 2018 р.). К., Національний військово-історичний музей України. — 2018. - С. 125-132.

\section{REFERENCES}

1. Nakaz Heneralnoho shtabu Zbroinykh Syl Ukrainy № 166 “Pro zatverdzhennia Prohramy zakhodiv shchodo vidnovlennia ta vprovadzhennia natsionalnykh boiovykh tradytsii u Zbroinykh Sylakh Ukrainy" vid 25.04.2018 [Order of the General Staff of the Armed Forces of Ukraine № 166 “On approval of the Program of measures for the restoration and implementation of national combat traditions in the Armed Forces of Ukraine" 25.04.2018].

2. Nakaz Ministerstva oborony Ukrainy vid № $91 \mathrm{KP}$ "Pro stan vprovadzhennia vymoh zakonodavstva Ukrainy shchodo zasudzhennia komunistychnoho rezhymu” vid 24.05.2018 [Order of the Ministry of Defense of Ukraine of № $91 \mathrm{KP}$ "On the state of implementation of the requirements of the legislation of Ukraine on condemnation of the communist regime" 24.05.2018].

3. Nakaz Ministerstva oborony Ukrainy № 343 «Pro zatverdzhennia Polozhennia pro orhanizatsiiu diialnosti viiskovykh muzeiv, muzeiv (kimnat) boiovykh tradytsii u Zbroinykh Sylakh Ukrainy” vid 17.07.2018 [Order of the Ministry of Defense of Ukraine № 343 “On approval of the Regulations on the organization of military museums, museums (rooms) of military traditions in the Armed Forces of Ukraine" 17.07.2018]. 
4. Metodychni rekomendatsii shchodo typovoi tematyky informatsiinoho napovnennia muzeinykh ekspozytsii viiskovykh muzeiv ta muzeiv (kimnat) boiovykh tradytsii viiskovykh chastyn, ustanov zakladiv Ministerstva oborony Ukrainy ta Zbroinykh Syl Ukrainy [Methodical recommendations on typical topics of information content of museum expositions of military museums and museums (rooms) of military traditions of military units, institutions of the Ministry of Defense of Ukraine and the Armed Forces of Ukraine].

5. Zborovskyi A. Vidobrazhennia heroizmu i trahedii irpinskykh uchasnykiv ATO v ekspozytsii Irpinskoho istoryko-kraieznavchoho muzeiu [Reflection of heroism and tragedy of Irpin participants of anti-terrorist operation in an exposition of the Irpin historical museum]: Materialy Vseukrainskoi naukovoi viiskovo-istorychnoi konferentsii (m. Kyiv, 19 kvitnia 2018 r.). K., Natsionalnyi viiskovo-istorychnyi muzei Ukrainy. 2018. pp. 211-213.

6. Zek B. Zakhody viiskovo-patriotychnoho spriamuvannia Volynskoho kraieznavchoho muzeiu u zviazku z provedenniam ATO i OOS na Donbasi [Military-patriotic events of the Volyn Museum of Local history in connection with the anti-terrorist operation and environmental protection in Donbas]: Materialy Vseukrainskoi naukovoi viiskovo-istorychnoi konferentsii (m. Kyiv, 19 kvitnia 2018 r.). K., Natsionalnyi viiskovo-istorychnyi muzei Ukrainy. 2018. pp. 204-207.

7. Davydiuk V. Komplektuvannia fondiv Natsionalnoho viiskovo-istorychnoho muzeiu ukrainy predmetamy iz zony ATO [Acquisition of funds of the National Military History Museum of Ukraine with items from the ATO zone]: Materialy Vseukrainskoi naukovoi viiskovo-istorychnoi konferentsii (m. Kyiv, 23 veresnia 2015 r.). K., Natsionalnyi viiskovo-istorychnyi muzei Ukrainy. 2015. pp. 261-270.

8. Tynchenko Ya., Korniienko O., Makhtarov D. Ekspozytsiino-vystavkova diialnist Natsionalnoho viiskovo-istorychnoho muzeiu Ukrainy, shcho vidobrazhaie aneksiiu Avtonomnoi Respubliky Krym ta voienni dii na skhodi krainy [Exposition and exhibition activity of the National Military History Museum of Ukraine, reflecting the annexation of the Autonomous Republic of Crimea and military actions in the east of the state]: Materialy Vseukrainskoi naukovoi viiskovo-istorychnoi konferentsii (m. Kyiv, 23 veresnia 2015 r.). K., Natsionalnyi viiskovo-istorychnyi muzei Ukrainy. 2015. pp. 271-293.

9. Moroz I., Liashenko K. Robota Natsionalnoho viiskovo-istorychnoho muzeiu Ukrainy z ushanuvannia pamiati zahyblykh u viini na Skhodi Ukrainy [The work of the National Military History Museum of Ukraine to honor the memory of those killed in the war in eastern Ukraine]: Materialy III Vseukrainskoi naukovoi viiskovo-istorychnoi konferentsii (m. Kyiv, 19 kvitnia 2018 r.). K., Natsionalnyi viiskovo-istorychnyi muzei Ukrainy. 2018. pp. 125-132. 
Pashkova O.O., Researcher of the research department of the history of wars and military art of the Research centre of military history of the National Defence University of Ukraine named after Ivan Cherniakhovskyi (Kyiv, Ukraine) ORCID: https://orcid.org/0000-0002-6525-4613

\section{ACTIVITIES OF MILITARY MUSEUMS IN MILITARY-PATRIOTIC EDUCATION OF CADETS OF HIGHER MILITARY EDUCATIONAL INSTITUTIONS OF UKRAINE} (2014-2019)

The article considers the main activities of domestic military museums during 2014-2019 in the context of military-patriotic education of future officers of the Armed Forces of Ukraine and preconscription youth. It was established that the renewal of the expositions of the museums of higher military educational institutions was carried out in accordance with the requirements of modern legal documents in the field of national memory and information security. Considerable attention in the article is paid to the reflection in the expositions of military museums of the participation of military units and individual servicemen in the anti-terrorist operation in eastern Ukraine.

Updated in 2014-2019, the expositions of museums of higher military educational institutions included photos of graduates who took part and/ordied during combatmissions, militaryequipment, documents, personal belongings, children's drawings and talismans made for servicemen who performed missions. in the area of the antiterrorist operation, information on awarding graduates of institutions with state awards of Ukraine, etc.

Weapons, uniforms of combatants, samples of ammunition used against Ukrainian forces, equipment of the Armed Forces of the Russian Federation and illegal armed groups were presented at the National Military History Museum of Ukraine and its branches. An important area of work of regional local historical museums of Ukraine was the recording of oral testimonies of direct participants in the antiterrorist operation, the Joint Forces operation, popularization of the contribution of local residents to protect the territorial integrity of the state, and militarypatriotic education of youth.

Key words: military museum, room of traditions, exposition, higher military educational institution, military-patriotic education, cadets, Armed Forces of Ukraine. 